Journal of Agricultural Sciences
(Tarim Bilimleri Dergisi)

\title{
Determination of the Seedling Reactions of Some Turkish Bread and Durum Wheat Cultivars to Stem Rust Races TTTTF, RTTTC and RTTTF
}

\author{
Nilüfer AKCi ${ }^{\mathrm{a}}{ }^{(\mathbb{D})}$, Aziz KARAKAYA ${ }^{\mathrm{b} *}$ (D) \\ ${ }^{a}$ Plant Protection Central Research Institute, Yenimahalle, Ankara, TURKEY

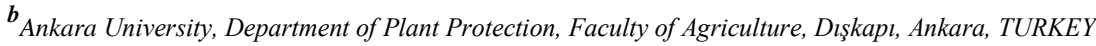 \\ ARTICLE INFO \\ Research Article \\ Corresponding Author: Aziz KARAKAYA, E-mail: karakaya@agri.ankara.edu.tr \\ Received: 14 February 2020 / Revised: 17 April 2020 / Accepted: 22 April 2020 / Online: 04 September 2021
}

\section{ABSTRACT}

Seedling resistance of 46 bread wheat and 14 durum wheat cultivars grown commonly in Turkey to stem rust races TTTTF, RTTTC, and RTTTF, the most common races in the Kastamonu region of Turkey, was determined under greenhouse conditions. Bread wheat cultivars Tahirova 2000, Yildırım, Alpu 2001, Canik 2003 and Basri Bey 95 were found to be resistant to three stem rust races. Durum wheat cultivars Sar
Çanak 98 and Furat 93 were resistant to stem rust race TTTTF. Durum wheat cultivars Eminbey, Altıntaş 95, Zühre and Sarı Çanak 98 were resistant to stem rust race RTTTC whereas durum wheat cultivars Eminbey, Altıntaş 95, İmren, Yelken 2000 and Zühre exhibited resistant reaction to stem rust race RTTTF. The majority of the wheat cultivars tested showed susceptible reactions to these stem rust races.

Keywords: Bread wheat, Durum wheat, Triticum spp., Stem rust, Puccinia graminis f. sp. tritici, Kastamonu, Turkey

(C) Ankara University, Faculty of Agriculture

\section{Introduction}

Wheat (Triticum spp.) is one of the most strategic crops in the world. It is the staple food in many countries because of its good food value, easy storage, handling, and processing (Geçit 2016). Wheat contributes greatly to the economy. It provides raw material to the agricultural industry and it is the main source of income for many rural areas. Wheat is commonly planted in Turkey (Taşçı et al. 2017). Rust diseases are among the most important biotic factors affecting the yield and quality of wheat plants. Stem rust disease caused by Puccinia graminis Pers. f. sp. tritici Erick \& Henn. is one of the oldest plant diseases known and causes significant losses in many areas of the world (Agrios 2005; Bockus et al. 2010; Singh et al. 2011). Although the disease is more common in stems of wheat, other above-ground portions of the plant could also be affected. The pathogen can form races and new races may render wheat cultivars susceptible to the disease. The Ug99 race emerged in Africa caused big losses in wheat production (Singh et al. 2011). Identification of the races of the pathogen and determination of the response of wheat cultivars to these races will have a great value in wheat production. The use of resistant cultivars is one of the most important control methods of stem rust disease (Knott 1989, Roelfs et al. 1992).

In a study conducted in Turkey, 21 different stem rust races of wheat were determined. Race TKTTC was the most common stem rust race (Mert et al. 2012a). Using the races TKTTC, RTKTF, and RTTTC, the seedling response of 97 bread wheat and 41 durum wheat cultivars were determined (Mert 2010). Also, seedling reactions of 28 bread wheat genotypes and 10 durum wheat genotypes were determined using these 3 races (Mert et al. 2012b).

In a study conducted in Kastamonu, Turkey, stem rust races TTTTF, RTTTC and RTTTF were found as the most common races (Akci and Karakaya 2021a). Stem rust races RTTTC and RTTTF have been reported from Kastamonu, Turkey (Mert et al. 2012a), previously and stem rust races TTTTF and RTTTF have been reported from Sinop, Turkey (Akci \& Karakaya 2019, 2021b). In this current study, under greenhouse conditions, the seedling response of 60 Turkish bread and durum wheat cultivars to these races was determined. The reactions of Turkish bread and durum wheat cultivars to stem rust races TTTTF and RTTTF were not determined previously.

\section{Material and Methods}

Under greenhouse conditions, seedling reactions of 46 bread wheat cultivars and 14 durum wheat cultivars grown in Turkey were determined against wheat stem rust races TTTTF, RTTTC and RTTTF. Bread and durum wheat seeds were planted into 
$150 \mathrm{~mL}$ pots containing soil: sand: animal manure (1:1:1). Each pot for inoculum enumeration and cultivar resistance studies included 8 plants. There were 6 plants in each pot for obtaining single pustule isolates. Plants were maintained in a controlled room at $15-20{ }^{\circ} \mathrm{C}$ with 16 hours light/8 hours dark conditions. For single pustule isolation and inoculum enumeration susceptible cv Demir 2000 was used. Plants were treated at the emergence stage with maleic hydrazide (0,001 g maleic hydrazide dissolved in $30 \mathrm{ml}$ water) for growth retardation and spore production was stimulated (Knott 1989). For inoculation, uredospores obtained from single pustules of the stem races TTTTF, RTTTF and RTTTC suspended in Soltrol 170® mineral oil were used (Akci and Karakaya 2021a). Inoculated plants were maintained in a humidity chamber with $95 \%$ relative humidity (RH) for 16 hours and then transferred to a greenhouse with a temperature regime of $20-25{ }^{\circ} \mathrm{C}$ and $60-80 \% \mathrm{RH}$. Inoculation was accomplished when plants were at the Zadoks growth stage 11 (Zadoks et al. 1974).

First disease evaluations were carried away 10 -12 days after inoculation. Two to three days later, a second disease assessment was accomplished. For disease assessment, a 0-4 scale was used (Roelfs \& Martens 1988). Infection types 0, ; 1, and 2 were considered low infection responses, and infection types 3 and 4 were considered high infection responses.

\section{Results and Discussion}

Seedling reactions of 46 bread wheat and 14 durum wheat cultivars to stem rust races TTTTF, RTTTC, RTTTF were determined under greenhouse conditions. Both resistant and susceptible cultivars and cultivars showing different reactions to these races were present (Table 1, Figures 1 and 2).

Table 1- Assessment of the seedling reactions of bread wheat/durum wheat cultivars to stem rust races TTTTF, RTTTC, RTTTF. For disease assessment, a 0-4 scale was used (Roelfs \& Martens 1988). Infection types 0, ; 1, and 2 were considered low infection responses, and infection types 3 and 4 were considered high infection responses

\begin{tabular}{|c|c|c|c|c|c|c|}
\hline No & $\begin{array}{l}\text { Bread } \\
\text { wheat/Durum } \\
\text { wheat }\end{array}$ & Cultivars & Developer & $\begin{array}{c}\text { Stem rust } \\
\text { race } \\
\text { TTTTF }\end{array}$ & $\begin{array}{l}\text { Stem rust } \\
\text { race } \\
\text { RTTTC }\end{array}$ & $\begin{array}{c}\text { Stem rust } \\
\text { race } \\
\text { RTTTF }\end{array}$ \\
\hline 1 & Bread wheat & İKİZCE 96 & TARM- ANK* & $3+$ & 3 & $3+$ \\
\hline 2 & Bread wheat & AKSEL 2000 & TARM- ANK & 4 & $3+$ & 3 \\
\hline 3 & Bread wheat & BAYRAKTAR 2000 & TARM- ANK & 4 & $3+$ & $3+$ \\
\hline 4 & Bread wheat & DEMIR 2000 & TARM- ANK & 3 & 3 & 3 \\
\hline 5 & Bread wheat & ATLI 2002 & TARM- ANK & 4 & 3 & $3+$ \\
\hline 6 & Bread wheat & ZENCİRCİ 2002 & TARM- ANK & 3 & $3+$ & $3+$ \\
\hline 7 & Bread wheat & ESER & TARM- ANK & $3+$ & $3+$ & $3+$ \\
\hline 8 & Bread wheat & SEVAL & TARM- ANK & 3 & 3 & 3 \\
\hline 9 & Bread wheat & TOSUNBEY & TARM- ANK & 3 & $3+$ & 3 \\
\hline 10 & Bread wheat & KENANBEY & TARM- ANK & $3+$ & $3+$ & $3+$ \\
\hline 11 & Bread wheat & LÜTFIBBEY & TARM- ANK & 3 & 3 & $3+$ \\
\hline 12 & Bread wheat & ALTAY 2000 & GKTAEM-ESK & 4 & $3+$ & $3+$ \\
\hline 13 & Bread wheat & ÇETİNEL 2000 & GKTAEM-ESK & $3+$ & 3 & 3 \\
\hline 14 & Bread wheat & ALPU 2001 & GKTAEM-ESK & $2+$ & $1+$ & 2 \\
\hline 15 & Bread wheat & İZGİ 2001 & GKTAEM-ESK & $3+$ & $3+$ & $3+$ \\
\hline 16 & Bread wheat & SÖNMEZ 2001 & GKTAEM-ESK & $3+$ & $3+$ & $3+$ \\
\hline 17 & Bread wheat & SOYER02 & GKTAEM-ESK & 3 & 3 & 3 \\
\hline 18 & Bread wheat & MÜFITBEY & GKTAEM-ESK & 4 & $3+$ & 3 \\
\hline 19 & Bread wheat & NACİBEY & GKTAEM-ESK & 3 & 3 & 3 \\
\hline 20 & Bread wheat & ES 26 & GKTAEM-ESK & 3 & $3+$ & $3+$ \\
\hline 21 & Bread wheat & YUNUS & GKTAEM-ESK & 3 & $3+$ & $3+$ \\
\hline 22 & Bread wheat & MESUT & GKTAEM-ESK & 4 & 3 & $3+$ \\
\hline 23 & Bread wheat & BAĞCI 2002 & BDUTAEM-KNYA & 4 & 3 & 3 \\
\hline 24 & Bread wheat & KONYA 2002 & BDUTAEM-KNYA & 3 & 3 & $3+$ \\
\hline 25 & Bread wheat & AHMETAĞA & BDUTAEM-KNYA & 3 & $3+$ & 3 \\
\hline 26 & Bread wheat & EKİZ & BDUTAEM-KNYA & $3+$ & $3+$ & 3 \\
\hline 27 & Bread wheat & ERAYBEY & BDUTAEM-KNYA & 3 & 3 & 3 \\
\hline
\end{tabular}


Table 1 (Continued) - Assessment of the seedling reactions of bread wheat/durum wheat cultivars to stem rust races TTTTF, RTTTC, RTTTF

\begin{tabular}{|c|c|c|c|c|c|c|}
\hline No & $\begin{array}{l}\text { Bread } \\
\text { wheat/Durum } \\
\text { wheat }\end{array}$ & Cultivars & Developer & $\begin{array}{c}\text { Stem rust } \\
\text { race } \\
\text { TTTTF } \\
\end{array}$ & $\begin{array}{l}\text { Stem rust } \\
\text { race } \\
\text { RTTTC }\end{array}$ & $\begin{array}{c}\text { Stem rust } \\
\text { race } \\
\text { RTTTF }\end{array}$ \\
\hline 28 & Bread wheat & KATE A-1 & TTAEM-EDRN & 4 & $3+$ & $3+$ \\
\hline 29 & Bread wheat & PEHLIVAN & TTAEM-EDRN & 3 & $3+$ & $3+$ \\
\hline 30 & Bread wheat & SELIMIYYE & TTAEM-EDRN & $3+$ & 3 & $3+$ \\
\hline 31 & Bread wheat & BEREKET & TTAEM-EDRN & 4 & $3+$ & $3+$ \\
\hline 32 & Bread wheat & CEMRE & $\begin{array}{l}\text { GAPUTAEM- } \\
\text { DYBKR }\end{array}$ & $3+$ & 3 & $3+$ \\
\hline 33 & Bread wheat & BEZOSTAJA-1 & MAEM-SKRY & 4 & $3+$ & $3+$ \\
\hline 34 & Bread wheat & TAHİROVA 2000 & MAEM-SKRY & $2+$ & 2 & 2 \\
\hline 35 & Bread wheat & BEŞKÖPRÜ & MAEM-SKRY & 4 & 3 & 3 \\
\hline 36 & Bread wheat & HANLI & MAEM-SKRY & $3+$ & 3 & 3 \\
\hline 37 & Durum wheat & KIZILTAN 91 & TARM- ANK & $3+$ & 3 & 3 \\
\hline 38 & Durum wheat & ÇEŞİT 1252 & TARM- ANK & 4 & $3+$ & $3+$ \\
\hline 39 & Durum wheat & MİRZABEY 2000 & TARM- ANK & 4 & 3 & $3+$ \\
\hline 40 & Durum wheat & EMINBEY & TARM- ANK & $3+$ & 2 & $2+$ \\
\hline 41 & Durum wheat & İMREN & TARM- ANK & $3+$ & 3 & 2 \\
\hline 42 & Durum wheat & ALTINTAŞ 95 & GKTAEM-ESK & $3-$ & 2 & ; \\
\hline 43 & Durum wheat & KÜMBET 2000 & GKTAEM-ESK & $3+$ & $3+$ & $3+$ \\
\hline 44 & Durum wheat & YELKEN 2000 & GKTAEM-ESK & $3+$ & No plants & $2++$ \\
\hline 45 & Durum wheat & DUMLUPINAR & GKTAEM-ESK & $3+$ & $3+$ & $3+$ \\
\hline 46 & Durum wheat & MERAM 2002 & BDUTAEM-KNYA & 3 & 3 & $3+$ \\
\hline 47 & Durum wheat & SARI ÇANAK 98 & $\begin{array}{l}\text { GAPUTAEM- } \\
\text { DYBKR }\end{array}$ & 2 & 2 & $3-$ \\
\hline 48 & Durum wheat & FIRAT 93 & $\begin{array}{l}\text { GAPUTAEM- } \\
\text { DYBKR }\end{array}$ & $2+$ & $3-$ & $3-$ \\
\hline 49 & Durum wheat & ZÜHRE & $\begin{array}{l}\text { GAPUTAEM- } \\
\text { DYBKR }\end{array}$ & 4 & $2+$ & $2++$ \\
\hline 50 & Durum wheat & GÖKGÖL 79 & TTAEM-EDRN & 4 & 3 & $3+$ \\
\hline 51 & Bread wheat & DAPHAN & DATAE-ERZRM & 4 & $3+$ & $3+$ \\
\hline 52 & Bread wheat & YILDIRIM & DATAE-ERZRM & 1 & $2+$ & 2 \\
\hline 53 & Bread wheat & AYYILDIZ & DATAE-ERZRM & $3+$ & 3 & $3+$ \\
\hline 54 & Bread wheat & CANIKK 2003 & KTAEM-SMN & $2++$ & 2 & $1+$ \\
\hline 55 & Bread wheat & ALTINDANE & KTAEM-SMN & 3 & $3+$ & $3+$ \\
\hline 56 & Bread wheat & CUMHURIYET 75 & ETAEM-İZM & $3+$ & $3+$ & $3+$ \\
\hline 57 & Bread wheat & BASRİ BEY 95 & ETAEM-İZM & $1+$ & $1+$ & $2+$ \\
\hline 58 & Bread wheat & KAŞİF BEY 95 & ETAEM-İZM & 3 & 3 & $3-$ \\
\hline 59 & Bread wheat & CEYHAN 99 & DATAEM-ADN & $3+$ & $3+$ & $3+$ \\
\hline 60 & Bread wheat & PANDAS (PANDA) & DATAEM-ADN & $3+$ & $3+$ & $3+$ \\
\hline
\end{tabular}

BDUTAEM/KNYA; Bahri Dağdaş International Agricultural Research Institute/Konya, DATAEM/ADN; Eastern Mediterranean Agricultural Research Institute./Adana, DATAE/ERZRM; Eastern Anatolia Agricultural Research Institute/Erzurum, ETAEM/IZM; Aegean Agricultural Research Institute/Izmir, GAPUTAEM/DYBKR; Southeast Anatolia Agricultural Research Institute/Diyarbakır, GKTAEM/ESK; Transitional Zone Agricultural Research Institute/Eskişehir, KTAEM/SMN; Black Sea Agricultural Research Institute /Samsun, MAEM/SKRY; Maize Research Institute/Sakarya *TARM/ANK; Central Research Institute for Field Crops/Ankara, TTAEM/EDRN; Trakya Agricultural Research Institute/Edirne

Five bread wheat cultivars (Tahirova 2000, Y1ldırım, Alpu 2001, Canik 2003 and Basri Bey 95) and 2 durum wheat cultivars (Sarı Çanak 98 and Firat 93) were found to be resistant to stem rust race TTTTF. Bread wheat cultivars Tahirova 2000, Yıldırım, Alpu 2001, Canik 2003 and Basri Bey 95 and durum wheat cultivars Eminbey, Altıntaş 95, Zühre and Sarı Çanak 98 showed resistant reactions to the stem rust race RTTTC. Bread wheat cultivars Tahirova 2000, Y1ldırım, Alpu 2001, Canik 2003 and Basri Bey 95 and durum wheat cultivars Eminbey, Altıntaş 95, İmren, Yelken 2000 and Zühre exhibited resistant reactions to stem rust race RTTTF. Bread wheat cultivars Tahirova 2000, Y1ldırım, Alpu 2001, Canik 2003 and Basri 
Bey 95 were found to be resistant to the 3 stem rust races used in our study. However, majority of the cultivars were susceptible to these stem races. Durum wheat cultivars Altıntaş 95, Eminbey and Zühre showed resistant reactions to stem rust races RTTTC and RTTTF. Durum wheat cultivar Sarı Çanak 98 showed resistant reaction to stem rust races TTTTF and RTTTC.
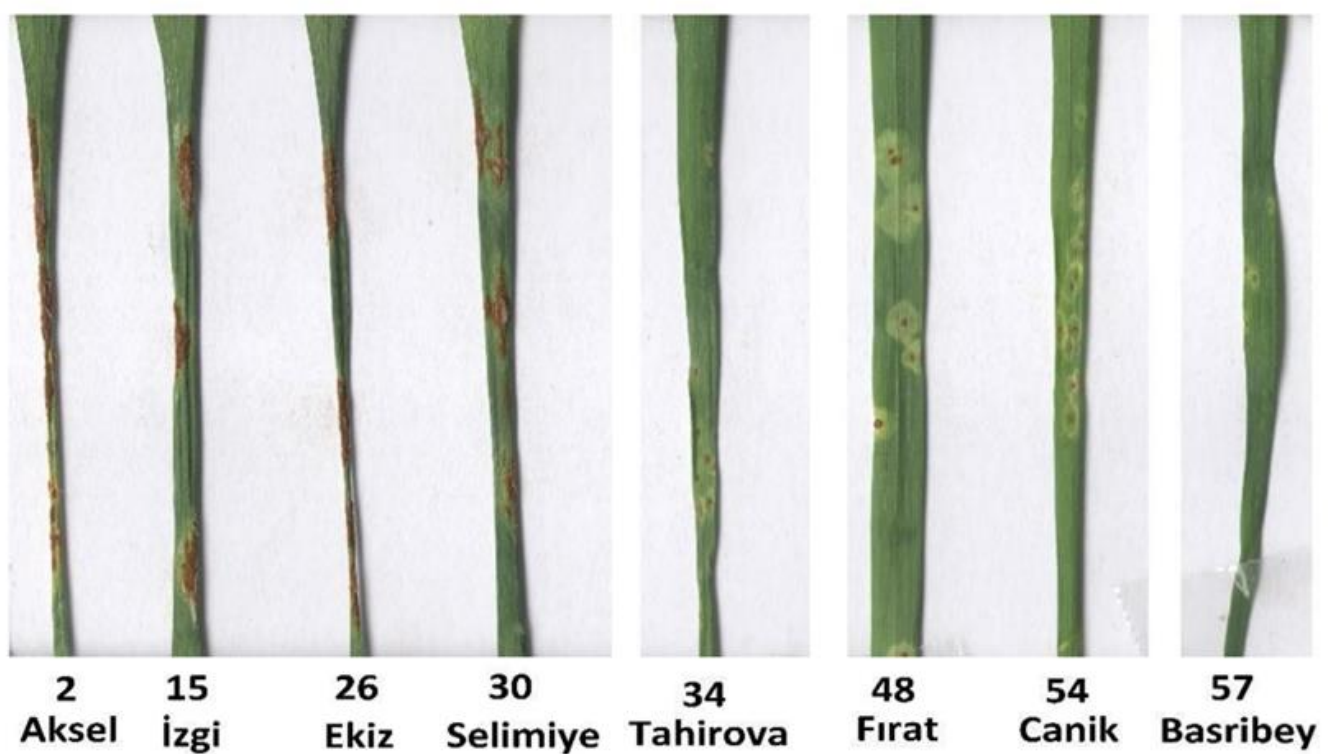

Figure 1- Reactions of some wheat cultivars to stem rust race TTTTF

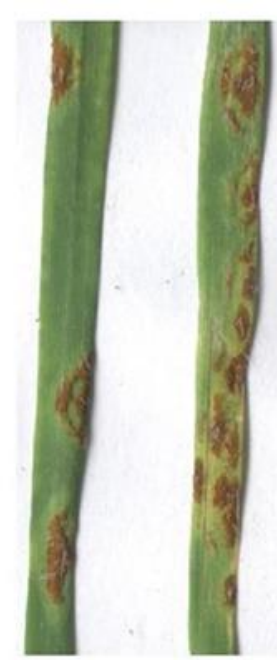

5

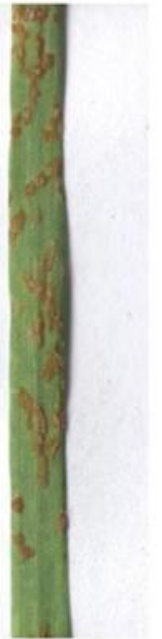

20

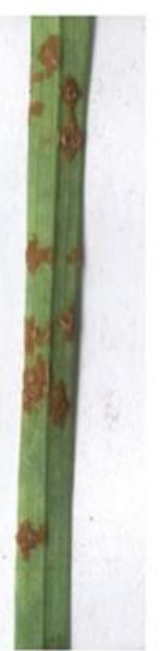

38

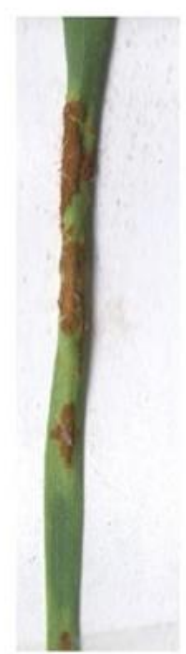

59

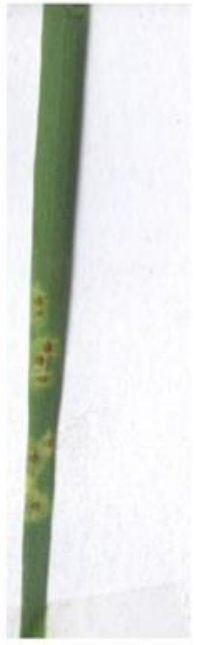

52

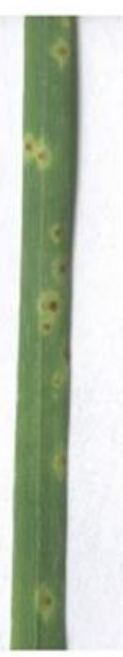

57

\section{Atlı Zencirci Es 26 Çeşit 1252 Ceyhan Yıldırım Basribey}

Figure 2- Reactions of some wheat cultivars to stem rust race RTTTF

Mert (2010), under greenhouse conditions, assessed the seedling stage reactions of 138 registered wheat cultivars in Turkey against wheat stem rust races TKTTC, RTKTF and RTTTC. Twelve bread wheat cultivars (Alpu 2001, Ahmetağa, Yıldırım, Karacabey 97, Tahirova 2000, Canik 2003, Köksal 2000, İzmir 85, Basri Bey 95, Menemen, Seri 82 and Carisma) and 9 durum wheat cultivars (Diyarbakır 81, Firat 93, Artuklu, Eyyubi, Turabi, Amanos 97, Balcalı 2000, Zenit and Svevo) were found resistant to these 3 races. In our study, bread wheat cultivars Tahirova 2000, Y1ldirım, Alpu 2001, Canik 2003 and Basri Bey 95 were found resistant to stem rust races TTTTF, RTTTC and RTTTF. In Mert (2010) study, bread wheat cultivars Ahmetağa, Alibey, Alpu 2001, Altay 2000, Ata 81, Atay 85, Aydın 98, Bağcı 2002, Basribey 95, Canik 2003, Carisma, Cemre, Çukurova 86, Dariel, Eser, Genç 99, Göksu 99, Gönen 98, Gün 91, Hanlı, İzmir 85, Karacabey 97, Karacadağ 98, Kaşifbey 95, Kınacı 97, Kırkpınar 79, Köksal 2000, Menemen, Nacibey, Nurkent, Pamukova 97, Saroz 95, Seri 82, Seyhan 95, Sultan 95, Süzen 97, Tahirova 2000, Tosun 144, Tosunbey, Uzunyayla, Yakar 99, Y1ldırım and Yıldız, durum wheat cultivars Amanos 97, Artuklu, Balcalı 2000, Ceylan 95, Diyarbakır 81, Eyyubi, Fırat 93, GAP, Gediz 75, İmren, Özberk, Pınar 2001, Sarı Çanak 98, Svevo, Turabi, Yelken 2000, Y1lmaz 98 and Zenit exhibited resistant reactions to stem rust race TKTTC. In our current research stem rust race TKTTC was not used. In our current study, bread wheat cultivars Tahirova 2000, Y1ldirım, Alpu 2001, Canik 2003 and Basri Bey 95 were resistant to the 3 stem rust races. These cultivars also exhibited resistance to race TKTTC 
(Mert 2010). In Mert (2010) study, bread wheat cultivars Ahmetağa, Alibey, Alpu 2001, Ankara 093/44, Ata 81, Aytın 98, Basri Bey 95, Bayraktar 2000, Beşköprü, Canik 2003, Carisma, Çukurova 86, Dariel, Genç 99, İkizce 96, İzmir 85, Karacabey 97, Kenanbey, Kırgız 95, Kırkpınar 79, Köksal 2000, Menemen, Nurkent, Özcan, Seri 82, Tahirova 2000, Uzunyayla, Yıldırım and Ziyabey 98, durum wheat cultivars Amanos 97, Ankara 98, Artuklu, Balcalı 2000, Ceyhan 95, Diyarbakır 81, Eyyubi, Firat 93, Özberk, Pınar 2001, Salihli 92, Sham 1, Svevo, Şahinbey, Turabi, Tüten 2002 and Zenit showed resistant reactions to stem rust race RTKTF. In our current research stem rust race RTKTF was not used. In our current study, bread wheat cultivars Tahirova 2000, Y1ldırım, Alpu 2001, Canik 2003, and Basri Bey 95 showed resistant reactions to the 3 stem rust races. These cultivars also exhibited resistance to race RTKTF (Mert 2010). In Mert (2010) study, bread wheat cultivars Ahmetağa, Alpu 2001, Ankara 095/44, Basribey 95, Canik 2003, Carisma, Esperia, İzmir 85, Karacabey 97, Karacadağ 98, Köksal 2000, Menemen, Seri 82, Tahirova 2000 and Yildırım, durum wheat cultivars Amanos 97, Ankara 98, Artuklu, Balcali 2000, Diyarbakır 81, Eyyubi, Fırat 93, GAP, İmren, Kümbet 2000, Pınar 2001, Salihli 92, Svevo, Şahinbey, Şölen 2002, Turabi, Tüten 2002, Yelken 2000, Y1lmaz 98 and Zenit showed resistant reactions to race RTTTC. In this study, relatively low numbers of resistant bread wheat cultivars to race RTTTC were observed as compared to bread wheat cultivars resistant to races TKTTC and RTKTF. In our current study we found the bread wheat cultivars Tahirova 2000, Y1ldırım, Alpu 2001, Canik 2003 and Basri Bey 95 and durum wheat cultivars Eminbey, Altıntaş 95, Zühre and Sarı Çanak 98 resistant to the stem rust race RTTTC. All bread wheat cultivars identified as resistant in our current study were also resistant in Mert (2010) study. Durum wheat cultivars Eminbey, Altıntaş 95 and Zühre were not used in Mert (2010) study. These cultivars were identified as resistant to race RTTTC with our current study for the first time. Mert (2010) study listed cv. Sarı Çanak 98 as susceptible (scale value 3 ). This cultivar showed a resistant reaction in our study (scale value 2). On the other hand, cv Firat 93 was reported as resistant (scale value 2+) in Mert (2010) study. This cultivar showed a susceptible reaction (scale value 3-) in our study. These cultivars showed reactions at the borderline between resistance/susceptibility. Bread wheat cultivars Tahirova 2000, Y1ldırım, Alpu 2001, Canik 2003 and Basri Bey 95 were resistant stem races TKTTC, RTKTF, RTTTC, TTTTF and RTTTF ((Mert (2010) and this study)), These bread cultivars can be planted in areas where these races are common. Also durum wheat cultivar Sarı Çanak 98 was identified as resistant to races TKTTC and RTTTC ((Mert (2010) and this study)). This cultivar can be planted in the areas where these stem rust races occur. Mert et al. (2012b) assessed the reactions of 28 bread wheat genotypes and 10 durum wheat genotypes to stem rust races TKTTC, RTKTF, and RTTTC. One bread wheat genotype and 2 durum wheat genotypes were resistant to three stem rust races. Twenty-three genotypes exhibited susceptible reactions to three stem rust races. The other twelve genotypes exhibited resistant and/or susceptible reactions to these stem rust races.

Stem rust race TTTTF was common in Kastamonu and Sinop provinces of Turkey (Akci \& Karakaya 2021a, 2021b). In 2008, stem rust races RTTTC and RTTTF were reported from Kastamonu-Ağlı and Kastamonu-Seydiler regions, respectively (Mert et al. 2012a). However, race TTTTF was not reported in their study. Recently, in addition to Turkey, this race has been reported from Italy (Patpour et al. 2018), Kenya (Wanyera et al. 2018) and Ethiopia (Abera et al. 2018). The reasons for the widespread appearance of this race in the Kastamonu and Sinop provinces of Turkey should be investigated.

\section{Conclusions}

Bread wheat cultivars Tahirova 2000, Yildırım, Alpu 2001, Canik 2003, and Basri Bey 95 were resistant to stem rust races TTTTF, RTTTC and RTTTF. While durum wheat cultivars Sarı Çanak 98 and Fırat 93 were resistant to stem rust race TTTTF, durum wheat cultivars Eminbey, Altıntaş 95, Zühre and Sarı Çanak 98 were resistant to stem rust race RTTTC and durum wheat cultivars Eminbey, Altıntaş 95, İmren, Yelken 2000 and Zühre exhibited resistant reaction to stem rust race RTTTF. Most of the cultivars exhibited susceptible reactions to these 3 stem rust races, however, resistant bread and durum wheat cultivars were also found. We identified resistant bread and durum wheat cultivars to stem rust races TTTTF and RTTTF for the first time in Turkey. Also, new cultivars resistant to race RTTTC were found. Resistant cultivars can be planted in the areas where these stem rust races occur.

\section{Acknowledgements}

This study was financially supported by the General Directorate of Agricultural Research and Policies, Turkey (Project No: TAGEM-BS-15\12-01\02-02). We thank the staff and research personnel of the Central Research Institute for Field Crops, Ankara, Turkey where this study was carried out.

\section{References}

Abera E H, Heyi N B, Wolderufael G W \& Tsegab T (2018). Virulence diversity of wheat stem rust (Puccinia graminis f. sp. tritici) in Ethiopia in 2016 main cropping season. BGRI Workshop, 14-17 April 2018. Marrakech, Morocco

Agrios G N (2005). Plant Pathology. $5^{\text {th }}$ Edition. Academic Press, San Diego, CA. USA

Akci N \& Karakaya A (2021a). Akci, N., Karakaya, A. 2021. Puccinia graminis f. sp. tritici races identified on wheat and Berberis spp. in northern Turkey. Indian Phytopathology (in press) doi.org/10.1007/s42360-021-00343-1

Akci N \& Karakaya A (2021b). Wheat stem rust races in Sinop, Turkey. Selcuk Journal of Agriculture and Food Sciences 35(1): 45-48 doi:10.15316/SJAFS.2020.227 
Akci N \& Karakaya A (2019). Detection of wheat stem rust race TTTTF in Turkey. Second International Conference on Advances in Plant Sciences, ICAPS 2019, 25-26 April 2019. Sarajevo, Bosnia and Herzegovina

Bockus W W, Bowden R L, Hunger R M, Morrill W L, Murray T D \& Smiley R W (eds.) (2010). Compendium of wheat diseases and pests. $3^{\text {rd }}$ ed. APS Press. 171 p. Minnesota

Geçit H H (2016). Serin iklim tahılları (Buğday, arpa, yulaf, triticale). Ankara Üniversitesi Ziraat Fakültesi Yayınları, Yayın No: 1640 Ankara

Knott D R (1989). The wheat rust-breeding for resistance. Monographs on Theoretical and Applied Genetics. 12. Springer-Verlag Berlin Heidelberg. 201 p. Germany

Mert Z (2010). Determination of races of wheat stem rust (Puccinia graminis f. sp. tritici) and resistant wheat genotypes against some races in Turkey. Ph. D. Thesis. Ankara University, Graduate School of Natural and Applied Sciences, Department of Plant Protection, Ankara, Turkey (in Turkish).

Mert Z, Karakaya A, Düşünceli F, Akan K \& Çetin L (2012a). Determination of Puccinia graminis f. sp. tritici races of wheat in Turkey. Turkish Journal of Agriculture and Forestry 36: 107-120 doi: 10.3906/tar-1010-1278

Mert Z, Karakaya A, Düşünceli F, Akan K \& Çetin L (2012b). Bazı buğday genotiplerinin kara pas hastalığının farklı ırklarına karşı reaksiyonlarının belirlenmesi. Bitki Koruma Bülteni, 52: 207-221

Patpour M, Hovmøller M S, Hansen J G, Justesen A F, Thach T, Rodriguez-Algab J, Hodson D \& Randazzo B (2018). Epidemics of yellow and stem rust in Southern Italy 2016-2017. BGRI Workshop, 14-17 April 2018. Marrakech, Morocco

Roelfs A P \& Martens J W (1988). An international system of nomenclature for Puccinia graminis f. sp. tritici. Phytopathology, 78: 526-533

Roelfs A P, Singh R P \& Saari E E (1992). Rust diseases of wheat: concepts and methods of disease management. CIMMYT 81 p. Mexico

Singh R P, Hodson D P, Huerta-Espino J, Jin Y, Bhavani S, Njau P, Herrera-Foessel S, Singh P K, Singh S \& Govindan V (2011). The emergence of Ug99 races of the stem rust fungus is a threat to world wheat production. Annual Review of Phytopathology 49: 465-481 doi.org/10.1146/annurev-phyto-072910-095423

Taş̧̧ı R, Kabalak S, Bolat M, Acar O, Şanal T, Pehlivan A, Külen S, Güneş E \& Albayrak N (2017). Ankara ilinde ekmekte tüketici tercihleri. Tarla Bitkileri Merkez Araştırma Enstitüsü Dergisi 26 (1):75-85 doi: 10.21566/tarbitderg.323599

Wanyera R, Wanga H, Kinyanjui P, Sridhar B \& Fetch T (2018). Report on rust incidence and races identified in Kenya during 2016 surveys. BGRI Workshop, 14-17 April 2018. Marrakech, Morocco

Zadoks C, Chang T T \& Konzak C F (1974). A decimal code for the growth stages of cereals. Weed Research 14: 415-421 doi.org/10.1111/j.1365-3180.1974.tb01084.x

(C) 2021 by the authors. Licensee Ankara University, Faculty of Agriculture, Ankara, Turkey.

This article is an open access article distributed under the terms and conditions of the Creative Commons Attribution (CC BY) license (http://creativecommons.org/licenses/by/4.0/). 